\title{
Kutü'l-Amare Zaferi, Türk Şehitliği ve Şehitlik Arazisinin Hediye Edilmesine İlişkin Değerlendirmeler
}

\author{
The Victory of Kutü'l-Amare, A Review of Turkish Martyrdom \\ and of the Donation of the Martyrdom Land
}

\begin{abstract}
Aydın BEDEN*
Öz: İngilizlerin 5 Kasım 1914'te, Osmanlı Devleti'ne resmen savaş ilan ederek, Irak'1 işgal etmeye başlamaları, 1918 Mondros Ateşkes Antlaşması'na kadar sürecek olan Irak Cephesi savaşlarının başlamasına sebep olmuştur. Irak Cephesi’ndeki Osmanlı Ordusu Kumandanı Süleyman Askeri Bey'in İngilizlere karşı başlatmış olduğu direniş, onun ardından komutayı devralan Nurettin Bey ile Halil Bey tarafindan da aynı azim ve kararlılıkla sürdürülmüştür. Özellikle 6. Ordu Komutanı olarak Halil Bey'in kazandığı Kutü'l-Amare Zaferi, tarihimizde unutulmaz bir başarı örneğidir. Nitekim Halil Bey, burada 29 Nisan 1916 tarihinde 13.309 mevcutlu İngiliz ordusunu esir ederek, gerek Türk gerekse İngiliz askeri tarihinde unutulmayacak bir yer edinmiştir. Bu bağlamda çalışmamız, Kutü'l-Amare Zaferi, özellikle de Kutü'l-Amare'de hayatlarını kaybeden askerlerimiz için yapılan Türk Şehitliği arazisinin Türkiye Cumhuriyeti'ne armağan edilmesine ilişkin olacaktır. Bu kapsamda, Kutü’l-Amare Zaferi'nin kazanıldığı toprakların bir bölümünün, 1933 yılındaki sahibi Rebia Emiri Ali El-Emir tarafindan Türk Hükümeti’ne armağan edilmesi ve karşılığında El-Emir'in ödüllendirilmesi konularında ne gibi çalışmalar yürütüldüğü ele alınacaktır. Ayrıca Kutü'l-Amare Zaferi ile şehitlik konusunda dikkat çeken birkaç noktaya da temas edilerek bazı değerlendirmelerde bulunulacaktır.
\end{abstract}

Anahtar sözcükler: Osmanlı Devleti, İngiltere, Irak Cephesi, Kutü’l-Amare, Türk Şehitliği

Abstract: The British invasion of Iraq in November 5, 1914 by officially declaring a war on the Ottoman State, triggered war on the Iraqi Front which continued until the Mudros Armistice Agreement of 1918.

The resistance against the British invaders was begun by Süleyman Askeri Bey, the Commander of the Ottoman Army on the Iraqi Front and was carried on with an equal resolution and determination by his successors Nurettin Bey and Halil Pasha. In particular, the Ottoman victory of Kutü'l-Amare won by Halil Pasha, the Commander of the 6th Army was an unforgettable example of victory. In consequence, Halil Pasha is integral to both British and Turkish military history through capturing the British army of 13.309 men who surrendered on the 29th of April 1916. In this context, this article concerns the victory of Kutü'lAmare and in particular the donation of the land for the cemetery of the Turkish Martyrs, which was made for the Turkish soldiers who lost their lives at Kutü'l-Amare, to the Republic of Turkey. Within this framework, the scope of the studies carried out concerning the donation of a part of the lands on which the Kutü'l-Amare victory was won were given to the Turkish Government by Ali El-Emir who was the Emir of Rebia and the owner of the land in 1933 and his being rewarded is discussed. In addition, a review is made concerning some significant points about the victory of Kutü'l-Amare and martyrdom.

Keywords: Ottoman State, Britain, Iraqi Front, Kutü'l-Amare, Turkish Martyrdom

\footnotetext{
*Yrd. Doç. Dr., Akdeniz Üniversitesi, Edebiyat Fakültesi, Tarih Bölümü, Antalya. aydinbeden@akdeniz.edu.tr
} 
23 Ekim 1914 günü Bahreyn Adalarını ele geçiren, 29 Ekim 1914 tarihli “Karadeniz Olayı"ndan sonra ise, 5 Kasım 1914'te, Osmanlı Devleti'ne resmen savaş ilan eden İngiltere, 6 Kasım'da Basra Körfezi'ndeki Fav Limanı'nı işgal ederek (Gn.kur. ATASE Başk. 1979, 69-71; Sâbis 1992, 215), I. Dünya Savaşı'nın Irak Cephesi’ni açmıştır.

22 Kasım'da Basra'ya hakim olan İngiltere, 9 Aralık’ta da Kurna'yı işgal ederek, bir ucu Fav limanı diğer ucu Kurna olan Şattü'l-Arab bölgesini bütünüyle ele geçirmiş oldu (Bayur 1991, C.III, Kısım: I, 399; Sâbis 1992, 216-217, 391-392).

İngilizlerin, Irak'a asker çıkarmaları ve işgal yolunda hızla ilerleyerek önemli başarılar kazanmaları, İstanbul'da büyük bir yankı uyandırdı. Bu yüzden hemen Irak'ta düşmana nazaran sayıca az olan Osmanlı kuvvetlerinin takviye edilmesi yoluna gidildi. Bu bağlamda Teşkilat-1 Mahsusa'nın başında olan Binbaşı Süleyman Askeri Bey, Enver Paşa tarafından, Kurna'da yenilen 38. Fırka'nın kumandasını almak üzere Irak'a gönderildi. Süleyman Askeri Bey'in Irak'taki görevi, İngilizlerin kuzeye doğru ilerlemesini durdurmak ve bedevi (yerli/Arap gönüllü) düzensiz kuvvetlerden oluşan bir ordu ile Basra'yı geri almak olduğu için son derece önemliydi (Özdemir 2004, 56; Gn.kur. ATASE Başk. 1979, 120; Sâbis 1992, 392-396).

Basra Valiliği ile Irak Kumandanlı̆̆ı'na atanan ve komutasinda sadece iki müfreze ile Osmancık Gönüllü Birliği bulunan Süleyman Askeri Bey (Gn.kur. ATASE Başk. 1979, 120; Özdemir 2004, 57) gerekli hazırlıkların ardından, bir İngiliz tugayının gerçekleştirdiği taarruz hareketini 20 Ocak 1915'te başarıyla geri püskürtmeyi başardı. Bu harekat, Irak'taki ilk başarılarımızdan biri olmuştur. Süleyman Askeri Bey'in yaralandığı bu saldırıdan sonra İngilizler, Basra'nın batısındaki Şuayyibe'de yığınak yapmak suretiyle savunmaya geçmişlerdir (Gn.kur. ATASE Başk. 1979, 126-129; Bayur 1991, C. III, Kisim: III, 91-92).

Bunun üzerine 11 Nisan'da Şuayyibe üzerine taarruza kalkan ve üç gün süren bu çarpışmalarda elindeki birliklerin yarısını, yaklaşık 3.800 askerini kaybeden, aşiret kuvvetlerinin de bir işe yaramadığını gören Askeri Bey, geri çekilmek zorunda kalmıştır. Askeri Bey, tüm gücüyle savaşmasına rağmen

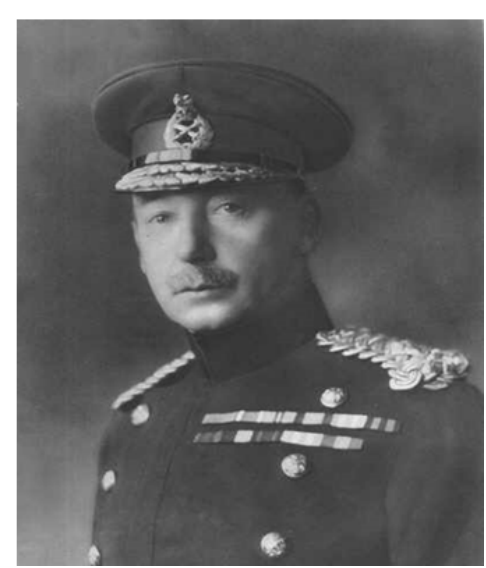

Fig. 1. General Townshend (18611924) Kaynak: Charles V. F. Townshend, Irak Seferi ve Esaret, (Terc. Tarih-i Asker-i Osmâni Encümeni), (Sad. Recep Ahıskalı) İstanbul 2007, 5 aldığ bu mağlubiyet karşısında dayanamayarak intihar etmiş-

tir (Bayur 1991, C. III, Kısım: III, 92-93; Sâbis 1992, 398-399; Townshend 2007, 64; Sakin 2010, 141). Sonuçta Şuayyibe Muharebesi ile Irak Cephesi'nin Askeri Bey komutasındaki ilk devresi, Osmanlılar açısından olumsuz bir şekilde sona erdi. İngilizler ise, Basra Vilayeti'nin Kurna'ya kadar olan kısmının güneyine yerleşti.

Askeri Bey'den sonra Irak Kumandanlı̆̆ı'na getirilen Albay Nurettin Bey ise Dicle Nehri'nin her iki yakasında bulunan ve savunulması güçleşen 38. Tümen'in geri çekilmesini istemiştir. Ancak nehrin sularının yükselmesi ve elde yeterli aracın bulunmaması nedeniyle 38 . Tümen, bu emri, İngilizler karşısında önemli kayıplar vererek gerçekleştirebildi ve Amare'ye çekildi. Bunu firsat bilen İngilizler de hedef olarak Amare'yi seçtiler (Ölçen 1992, 9).

$\mathrm{Bu}$ arada Irak'taki İngiliz kuvvetleri iki tümenlik kolorduya çıkarılmış ve komutasına General Nixon getirilmişti. Tümgeneral C. V. F. Townshend ise 22 Nisan 1915'te bu tümenlerden 6. Tümen'in komutasını devralmıştır. Bu değişim, artık savaşın Londra'dan değil Delhi'deki Hindistan Hükümeti tarafından idare edileceği anlamına geliyordu. Cephedeki İngilizler ise 24 Mart 1915 tarihli yönerge doğrultusunda (Bayur 1991, C. III, Kısım: III, 100; Üzen 2008, 82; 
Erickson 2009, 123-124.), hedef olarak seçtikleri Amare'yi, 31 Mayıs'tan itibaren sayı ve silah üstünlükleri ile nehir üzerinde işleyen topçekerlerin ateşi sonucunda ele geçirdiler (3 Haziran 1915) (Townshend 2007, 109-117; Sakin 2010,144). 23-25 Temmuz çarpışmalarından sonra da birçok zayiatlarına rağmen Nasıriye'yi işgal ettiler. Artık sıra Kutü'l-Amare'ye gelmişti (Longrigg 1968, 80; Sakin 2010,144; Bayur 1991, C. III, Kısım: III, 100).

\section{Kutü'l-Amare Muharebeleri}

Amare ve Nasıriye'nin elden çıkması neticesinde Albay Nurettin Bey, Kutü'l-Amare'de savunmaya geçmeye karar vermişti. Zira, Kutü'l-Amare'nin elde bulundurulması sayesinde Bağdat'ın savunmasının kolaylaşacağı düşünülüyordu. Bu amaçla ağır kayıplar veren Türk birlikleri ile Irak ve Havalisi Genel Komutanlığı Kutü'l-Amare'ye nakledildi (Gn.kur. ATASE Başk. 1979, 334-337; Ölçen 1992, 10). Buna karşın 23 Ağustos’ta harekat emri alan General Townshend komutasındaki İngiliz askerleri, 27 Eylül'de Dicle Irmağı'nı takip etmek suretiyle Kutü'lAmare'ye doğru taarruza geçtiler (Townshend 2007, 148-151, 192). Bu şekilde yapılacak ani bir saldırıyla Dicle Nehri'nin kuzey sahillerindeki Türk birliklerinin kuşatılması ve imha edilmesi öngörülmekteydi. Albay Nurettin ise Selman-1 Pak mevziisine çekilmekten ve Kutü'l-Amare'yi İngilizlere terk etmekten başka bir çözüm yolu bulamad. Böylece Kutü'l-Amare'yi 28 Eylül'de ele geçiren İngilizler, Aziziye'ye kadar ilerlediler (Longrigg 1968, 80; Gn.kur. ATASE Başk. 1979, 366-369; Townshend 2007, 196-200).

Kutü'l-Amare yenilgisi, Başkomutanlık Karargahı'ndaki mevcut endişeyi büsbütün artırdı. Bunun üzerine 13. ve 18. Tümenler, hemen Irak Kumandanlığ 1 emrine verildi. Irak'taki tüm ordular da 6. Ordu çatısı altında topland1. 6. Ordu Komutanlığı'na Alman Mareşali Von Der Goltz getirildi (T.C. Başbakanlık Devlet Arşivi Gen. Müd. 1993, 54-55; Erickson 2009, 118; Sorgun 2010, 124-125).

Kutsal Kerbela şehri yakınlarında ve Bağdat'a $30 \mathrm{~km}$. mesafede bulunan Selman-1 Pak bölgesinde hazırlıklarını tamamlamış bir vaziyette düşmanı bekleyen Nurettin Bey, vakit kaybetmek istemeyen İngiliz ordusunun 21 Kasım'da tekrar taarruza kalkmasıyla isteğine ulaştı. İngilizlerin taarruzuna karşılık Nurettin Bey de hemen karşı taarruza geçti ve üç gün boyunca şiddetli çarpışmalar yaşandı. Sonuçta General Townshend komutasındaki İngiliz ordusu yenildi ve bazı birlikleri bozulmuş bir halde 25 Kasım'dan itibaren Kutü'l-Amare'ye doğru geri çekilmek zorunda kaldı (Harp Mecmuası 2006, 78; Townshend 2007, 285-312; Goltz 2012, 137-138; Sakin 2010, 149). Türk birlikleri ise savaşı bırakmayarak, takip harekatına başladılar. Öyle ki, Aziziye mevkiinde, neredeyse İngilizlerle içiçe geçmiş olan Türk birlikleri, burada İngilizlerle tekrar çatışmaya girdi ve İngilizlere ikinci yenilgilerini burada yaşattılar (Apak 1988, 134-135; Gn.kur. ATASE Başk. 1979, 407-420). 3 Aralık'ta Kutü'l-Amare'ye ulaşan İngiliz birlikleri, yaklaşan Türk birliklerine karşı derhal kasabada savunma tedbirleri almaya başladılar. Kasabada daha önce birakılan kuvvetlerle birlikte Townshend komutasında; 300'ü subay olmak üzere 2.850 İngiliz, 8.250 Hintli subay ve er ile geri hizmetlerinde görev yapan 3.500 Hintli hizmetli bulunuyordu (Üzen 2008, 82).

\section{Kutü'l-Amare Kuşatması ve Zaferi}

Selman-1 Pak'taki başarılar sonrasında Kutü'l-Amare üzerine iki saldırı yapan Nurettin Bey, sonuç alamayacağını anlayınca, 6. Ordu Komutanlığı'na getirilen Goltz Paşa'nın önerisi ile Townshend ordusunu kuşatma altına aldı (Goltz 2012, 139). Türk ordusunun kuşatması 5 Aralık 1915'de başlayıp 7 Aralık'ta tamamlanmıştır. Townshend, General Nixon'un en geç iki ay içerisinde yardıma geleceğini düşündüğü için özellikle yiyecek miktarını azaltmamaya gayret ediyordu. Çünkü askerlerinin, kurtarma kuvvetleriyle birleştiği zaman zinde ve sağlıklı olmasını istiyordu (Barber 1918, 56-61; Üzen 2008, 86-87,90-91; Erickson 2009, 129-130). Türk ordusu 
kumandanı Nurettin Bey ise bu sırada Goltz Paşa ile Kut'un alınması konusunda bazı çatışmalara girmişti. Goltz Paşa, Kut'u saldırı yerine açlıkla ele geçirmeyi düşünürken Nurettin Bey saldırıyı ön planda tutmaktaydı. Hatta 9 Aralık'ta ve Goltz Paşa'nın teftiş için İran'a gittiği bir zamanda 24 Aralık'ta olmak üzere Kut'a başarısız iki saldırı yaptırmıştır (Barber 1918, 84-85; Üzen 2008, 86; Erickson 2009, 130-139). İşte tam bu sırada Türk ordusunda Nurettin Bey görevden alındı, yerine Albay Halil Bey getirildi (10 Ocak 1916) (Bayur 1991, C. III, Kısım: III, 104; Goltz 2012, 143; Sorgun 2010, 126).

Kutü'l-Amare, Dicle Nehri'nin bir büküm noktasında olup, üç yanı ırmaklarla kuşatılmış bir bölgeydi. Açık kalan diğer tarafi ise $1200 \mathrm{~m}$ uzunlugundayd1. Bu nedenle orayı savunmak ve yardım beklemek son derece kolaydı (Bayur 1991, C. III, Kısım: III, 104; Erickson 2009, 130-139). Ancak burada savunmaya geçmek, aynı zamanda sıkışıp kalmak anlamına geliyordu. Zaten İngilizler de Dicle'nin sol sahilindeki bir dere üzerinde olan Kut'a girerek, adeta dere içinde sıkışıp kalmışlardı. Nehrin sağ tarafina geçip yoluna devam edebilmesi için de köprüsü yoktu. Neredeyse Türk kuvvetlerinin avuçlarının içine girmiş denilebilirdi. Bu konuda Halil Bey, kuşatma

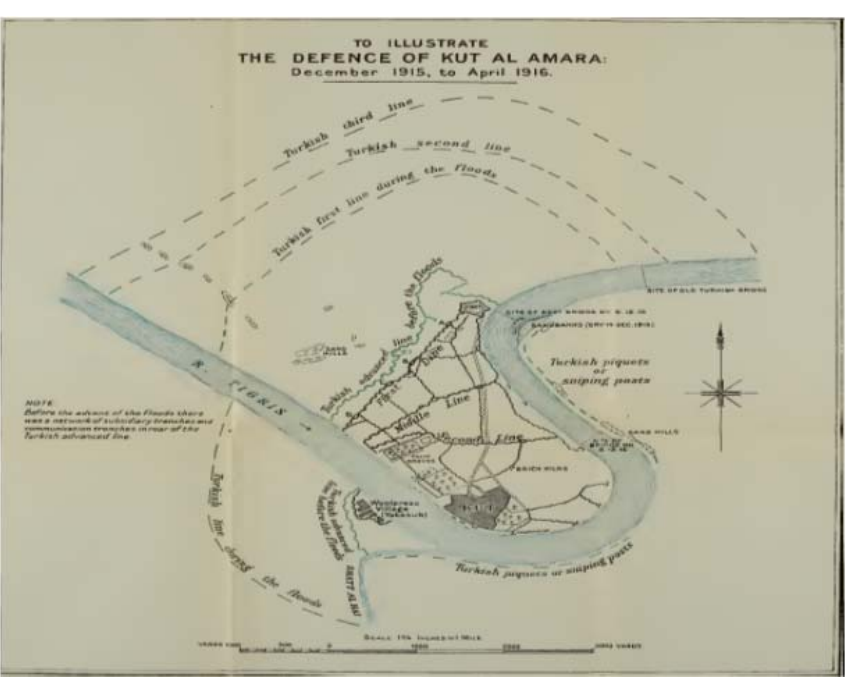

Fig. 2. Kutü'l-Amare Kuşatması (Aralık 1915 - Nisan 1916) Kaynak: F. J. Moberly, The Campaign in Mesopotamia 1914-1918, Volume II, London, 1924, Map: 11. hattı kuvvetlendikçe, İngilizlerin, yardım gelme ihtimali olan Basra istikametine doğru ilerlemeye çalıştıklarını ve gün geçtikçe kuvvetten düştüklerini ifade etmektedir (Sorgun 2010, 123).

Kutü'l-Amare'deki General Townshend Tümeni'nin durumu bu şekilde iken, taze kuvvetlerle beslenen diğer İngiliz birlikleri kurtarma harekatı için hazırlıklara girişmişti. İngilizlerin askeri açıdan kurtarma denemeleri de Ocak ayının başlarından Mart ayı sonlarına kadar devam etmesine karşın Türk kuşatması bir türlü kırılamamış ve her seferinde başarısızlıkla sonuçlanmıştır (Bayur 1991, C. III, Kısım: III, 104; Ölçen 1992, 15-20, 23; Harp Mecmuası 2006, 78, 274-275; Sorgun 2010, 129-140). Böylece Kutü'l-Amare'de kuşatılmış olan 6. İngiliz Tümeni'nin kurtarılma ümitleri kalmamıştı. Bunun üzerine General Lake, General Townshed'a teslim koşullarını konuşma yetkisi verdi (Gn.kur. ATASE Başk. 1979, 776; Townshend 2007, 565569). Müzakerelerde General Townshend; I. Dünya Savaşı'nın bundan sonraki safhasında Osmanlı askerleri aleyhine herhangi bir girişimde bulunmayacağını, ellerinde bulunan 40 top ile cephaneyi Osmanlı ordusuna teslim edeceğini ve Halil Bey'in şahsına yazılmış bir milyon İngiliz sterlini tutarındaki çekin kabul edilmesini istemişti. Karşıllğında ise İngiliz kuvvetleri esir alınmayacak, Basra istikametine doğru çekilmelerine izin verilecekti. Böylesi tekliflerle, hele de son teklifle muhatap olan Halil Bey, oldukça sinirlenmiş olacak ki, “...tek cevap, silâhımın namlusundan çıkacak tek bir kelime olurdu ..." diyor kendi kendine (Hiçyılmaz 2002, 73-74; Townshend 2007, 569-570 (dp.255); Sorgun 2010, 141-142). Yani, taraflar arasinda uzlaşma sağlanamamıştır.

Gerçekten de İngilizlerin izledikleri strateji çok ilginçti. Rüşvet teklifleri İngiliz Generali Robertson'dan gelmişti. Robertson, Yüzbaşı Lawrence'e gönderdiği telgrafta; “...Mezopotamya'daki Türk liderlerden mesela Halil Paşa'yı veya Necip'i satın almaya bak ki, ancak bu 
şekilde Townshend ve askerleri serbest kalabilir. Bu vazife için sana rüşveti bir milyon sterline kadar yükseltmek hakkı tanınmıştır..." diyordu (Hiçyılmaz 1996, 143) ve yukarıda bahsettiğimiz müzakeredeki teklifin de bu olması gerekiyor. Hatta Halil Bey tarafindan reddedilen bu teklifin miktarı daha sonra arttırılarak, kılıf değiştirilmiş hali tekrar öne sürülmüştür. Buna göre Lawrence, "Türkiye Hükümeti namına iki milyon İngiliz liralık çek" teklif ediyordu. Halil Bey ise, hükümetinin paraya ihtiyacı olmadığını belirterek bu teklifi de geri çevirmiştir (Hiçyılmaz 2002, 74; Sorgun 2010, 142-143; İlhan 2015, 13).

Müzakerelerin bu şekilde akim kalması ve Türk tarafının kayıtsız şartsız teslim konusunda 1srarı neticesinde 29 Nisan 1916'da İngiliz birlikleri 2.000 mevcutlu Türk askerine teslim olmak zorunda kaldı. Halil Bey, Kut'u teslim aldığı zaman Townshed'un kendisine kılıcı ile tabancasını uzattığını görünce; "kılıç ve tabancanız, şimdiye kadar olduğu gibi daima size aittir" demiş ve ardından "Generalim! Siz ordunuzun ve milletinizin şerefini tamamen müdafaa ettiniz, vaziyetiniz kismen Plevne'deki Gazi Osman Paşa'nın vaziyetidir. Sizi harp esiri olarak kabul etmiyorum, Padişah 'ın ve Türk milletinin misafirisiniz..." diyerek geleneksel Türk hoşgörüsünü bir defa daha göstermiştir (Townshend 2007, 570; Sorgun, 2010, 143-144). Kutü'l-Amare'de teslim olan İngiliz personelinin durumu şu şekildeydi (Gn.kur. ATASE Başk. 1979, 780; Ölçen 1992, 24);

$\begin{array}{ll}\text { General } & 5 \\ \text { İngiliz Subay1 } & 272 \\ \text { Hind Subay1 } & 204 \\ \text { İngiliz Eri } & 2.592 \\ \text { Hintliler } & 6.988 \\ \text { Gayr-i muharipler } & 3.248 \\ \text { Toplam } & 13.309\end{array}$

\section{Kutü’l Amare Zaferi’nin Sonuçları ve Önemi}

Osmanlı Devleti'nin İngilizlerle yapmış olduğu Irak Cephesi'ndeki savaşlar genel anlamda her ne kadar İngilizlerin üstünlüğü ile sonuçlanmış olsa da Türk tarafının kazanmış olduğu 'Kutü'lAmare Zaferi" her iki ulusun da tarihinde unutulmayacak bir yer edinmiştir.

En başta bu zafer ve esir edilen İngiliz askeri, Britanya ordularının 1781 Yorktown ve 1942 Singapur yılları arasında yaşamış olduğu tek en büyük teslimiyet olmuştur. İngilizlere göre, "aşağı ırklar"ın kuşatmalarına başarıyla direnme geleneğine sahip olan ulusları için Kutü'lAmare teslimiyeti oldukça aşağılayıcıydı. Çünkü orduları, ölmek üzere olan "Hasta Adam"1n ordularına teslim olmuştu (Erickson 2009, 103).

Diğer taraftan bu hezimetin Çanakkale yenilgisinden hemen sonra yaşanması, Britanya yönetiminde yanlış giden bir şeylerin olduğu düşüncesini doğurmuştur. Bu sebeple, yanlışın bulunup düzeltilmesi ve nasıl hareket edilmesi gerektiğinin araştırılması için parlamento komisyonlarının oluşturulmasına sebep olmuştur (Erickson 2009, 103).

Üstelik İngilizlerle birlikte Batı dünyası da bu yaşanılan yenilgiyi, kesinlikle görmezden gelmiş, unutulmak istenilen bir vakıa olarak değerlendirmiştir. Nitekim Batılı kaynakların çoğunda savaşla ilgili olarak daha çok Tümgeneral Charles Townshend ile Hint 6. Piyade Tümeni'nin kuşatma sırasında çektikleri sıkıntılar üzerinde durulması, savaşa ve alınan neticeye hiç değinilmemesi, Türkler açısından tam bir zafer, İngilizler açısından ise tam bir hezimet olan bu savaşın bilinçli olarak ihmal edilip unutturulmaya çalışıldığını göstermektedir (Erickson 2009, 104). 
Türkler için ise Kutü'l-Amare tam bir zaferdi ve yorgun askeri birliklere heyecan, canlılık ve şevk vermişti. Verilen mücadele ile bütüncül anlamda kazanılan tek cephe olan Çanakkale Zaferi'nden sonra Osmanlı ordularının İngilizlere karşı kazandığı ve bir İngiliz tümenini esir ettiği en önemli başarıdır. Bu durum, asker ve millete topyekün bir moral ve motivasyon kaynağı olmuştur.

Öyle ki, ordu komutanı Halil Bey, İngiliz askerlerinin teslim alınmasının ardından, 29 Nisan 1916'da, askerlerine yaptığ 1 konuşmada; kendilerini verdikleri amansız mücadeleden ötürü kutlamış ve bugünü (29 Nisan) "Kut Bayramı" olarak ilan ettiğini bildirerek, her yıl bugün şehit askerlerimize dualar edilmesini istemiştir (Sorgun 2010, 143-144). Üstelik Osmanlı'nın lekelenmiş namını yeniden parlatan Albay Halil Bey'e, buradaki başarısından ötürü "Paşa" unvanı verilmiş, kendisi Kutü'l-Amare fatihi olarak alkışlanmış ve soyadı kanunun çıkması üzerine de "Kut" soyadını almıştır (Erickson 2009, 150).

Kutü'l-Amare Zaferi'nin Türk tarafı açısından en önemli sonuçlarından bir diğeri hiç şüphesiz Musul Meselesi bağlamında kaşımıza çıkmaktadır. Öyle ki burada elde edilen başarılar neticesinde İngilizlerin Irak Cephesi'ndeki ilerleyiş-

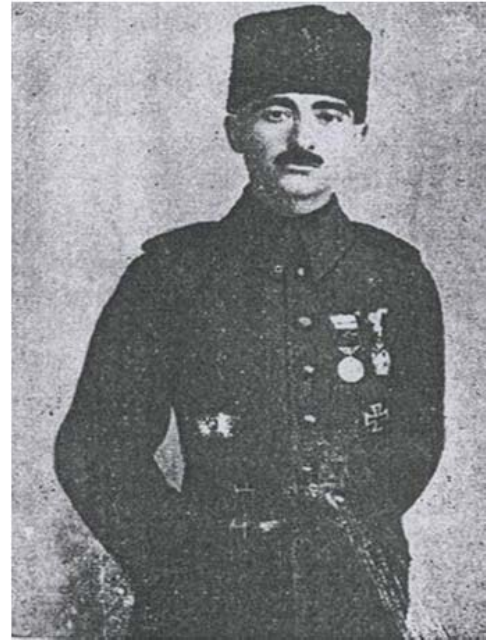

Fig. 3. Kut'ül-Ammare Kahraman Halil (KUT) Paşa. Kaynak: Talyan Sorgun, Halil Paşa Ittihat ve Terakki'den Cumhuriyete Bitmeyen Savaş. İstanbul, 2010, s.287. leri altı aylık bir duraksama dönemine girmiş, dolayısıyla Bağdat ve Musul Vilayetlerinin işgal süreci gecikmiştir. Kutü'l-Amare kaynaklı gecikmeden ötürü Musul ve çevresi, ancak 30 Ekim 1918 tarihli Mondros Mütarekesi'nin imzalanmasından sonra, o da savaş sona erdiği için haksız bir şekilde işgal edilmiştir. Haklılığını, gerek Lozan Barış Konferansı gerek Haliç Konferansı gerekse de Milletler Cemiyeti gibi hemen hemen her platformda dile getiren Ankara, her ne kadar amacına ulaşamamış olsa da, 5 Haziran 1926 tarihli Ankara Antlaşması'nı imzalamayarak bazı haklar elde etmeyi başarmıştır.

Ayrıca Kutü'l-Amare Zaferi'nin hemen ardından alınan hatalı bir karar, her ne kadar İngilizlerin ilerlemesine zemin hazırlamışsa da bazı olumlu sonuçlarının da olduğu unutulmamalıdır. Şöyle ki, Halil Bey, Kutü'l-Amare'nin kurtarılmasından sonra derhal orduyu düzene sokup, Kutü'l-Amare'ye gelen yardımcı İngiliz birliklerini Basra'dan geri atmayı düşünüyordu. Ancak tam bu sırada, Başkumandanlık Karargâhı, Irak Cephesi'ndeki 13. Kolordu'yu, İran'daki Rusları dağıtmak gerekçesi ile İran'a gönderilmesi emrini vermiştir (Mehmet Kenan 1928, 220; Sorgun 2010, 147-150). Görevini başarıyla yerine getiren 13. Kolordu, sadece Irak sınırına yaklaşan Rus kuvvetlerini durdurmakla kalmamış, aynı zamanda Hamedan ve Kirmanşah'a kadar ileri harekata geçmiştir (Longrigg 1968, 87; Gn.kur. ATASE Başk. 2002, 52-53). Dolayısıyla 13. Kolordu'nun İran'daki başarıları her ne kadar Irak Cephesi'nde zafiyet yaratmışsa da Irak'ın kuzeydoğusundan başlayacak bir Rus işgalinin önüne geçmiştir. İki müttefik gücün Irak üzerinden birbirleriyle doğrudan irtibata geçmesinin böylelikle engellenmiş olması, gerek savaşın kaderini, gerekse Osmanlı Devleti'nin geleceğini etkileyen önemli bir hamle olmuştur.

\section{Kutü'l-Amare Şehitliği Arazisi'nin Türk Hükümeti’ne Hediye Edilmesi}

Kutü'l-Amare'de İngilizlere karşı verilen mücadelenin ebedileşmesi ve orada hayatlarını kaybeden askerlerimizin destansı mücadelelerinin bir nişanesi olmak üzere aziz şehitlerimize daimi bir ikametgah hazırlanması, elbette ki Türkiye Cumhuriyeti'nin en önemli tarihi vazifelerinden biri olmuştur. 
$\mathrm{Bu}$ vazifenin icrası, aslında Kutü'l-Amare Zaferi'nden hemen sonra orada inşa edilen bir abide ile şehitliğin hazırlanması suretiyle 1916 yılında Türk ordusu tarafından gerçekleştirilmişti. Ancak Türk Şehitliği’nin bulunduğu arazi, Irak topraklarının elimizden çıkıp bu topraklar üzerinde Irak Devleti'nin kurulması üzerine, şahsi mülk toprakları içerisinde yer almıştır. $\mathrm{Bu}$ bağlamda Türk Şehitliği arazisi, Irak Vatandaşı Rebia Emiri Ali El-Emir'in şahsi mülkü haline gelmiştir. Ancak Rebia Emiri Ali El-Emir'in 1932 yllında söz konusu araziyi Türkiye Cumhuriyeti'ne hibe etmeye karar vermesi, şehitlik konusundaki son pürüzün çözümlenmesi için Irak Kralı ve Hükümeti ile Türkiye'nin Bağdat Elçiliği, Bağdat Elçiliği ile Hariciye Vekaleti ve Hariciye Vekaleti ile Başvekalet arasında uzun soluklu bir yazışma trafiğinin gerçekleşmesine sebep olmuştur. Sonuçta, şehitlik arazisi konusundaki sorun çözümlenmiş, Türk Hükümeti de Rebia Emiri Ali El-Emir'i bir vefa ve minnet borcu olarak ödüllendirmek istemiştir.



Fig. 4 Kut Türk Şehitliği Abidesi Kaynak: http://www.msb.gov.tr/Sehit likler/YurtDisiSehitlikleri

Türkiye'nin Bağdat Elçiliği tarafından verilen bilgilere göre; yazışma trafiği ilk olarak, arazi sahibi Irak şeyh ve eşrafından Rebia Emiri Ali El-Emir ile Irak Hükümeti arasında gerçekleşmiştir. Çünkü Irak kanunları, bir kişinin yabancı bir devlete doğrudan doğruya arazi hibe etmesine müsaade etmemekteydi. Dolayısıyla feragat işlemlerini kanuna uygun hale getirmek amacıyla, Ali El-Emir şehitlik arazisini önce Irak Hükümeti'ne bağışlamıştır (BCA., 30..10.0.0 / 259.744..7., 5 (1935.12.2))

Ardından Irak Hariciye Vezareti, 24 Eylül 1932 tarihli ve 6273 sayılı yazısına ek olarak durumu Irak Meclis-i Vüzerası'na arz etmiştir. Meclis de 20 Nisan 1933 tarihli oturumunda konuyu görüşmüş ve Irak'ın Kut Kasabası'nda olup, Türk Şehitliği olarak kabul edilen ve 2 numarada ve 1/17 (Meclis kararında arazinin silsile numarası her ne kadar 1/71 olarak verilmişse de aynı silsile numarasının Irak Kralı'nın irade-i kraliyesinde 1/17 olarak geçtiği görülmektedir. Bk. BCA., 30..10.0.0 / 259.744..7., 8 (1935.12.2). Bu bağlamda, 2/17 silsile numaralı arazi ile bu arazinin yan yana olduğu düşünülürse diğer silsile numarası ile paralellik arz etmesi gerektiğinden, bu durumun sehven yanlış yazımdan kaynaklandığ düşünülebilir ve doğru olan numaranın 1/17 silsile numarası olduğu kabul edilebilir.) silsile nolu Irak Hazinesi'ne kayıtlı, $7988 \mathrm{~m}^{2}$ yüzölçümünde olan ve doğudan Dicle Nehri ile ve kuzey, batı, ve güneyden 2/17 silsile no ile kayıtlı Damuk Nehri arazisi ile sınırlı bulunan bir kıt'a arazinin Türkiye Cumhuriyeti'ne mülk olarak verilmesine karar vermiştir (BCA., 30..10.0.0 / 259.744..7., 7 (1935.12.2)).

Meclis kararının alınmasından sonra 29 Nisan 1933 tarihinde Irak Kralı; Maliye Veziri'nin maruzatına binaen, hükümete ait bina ve arsaların mülk edinme hakkındaki kanununun birinci maddesinin birinci fikrasını hatılatarak, ilgili arazinin Türkiye Cumhuriyeti'ne temlik edilmesi hususundaki 118 sayılı iradesini yayınlamıştır. Bu irade-i kraliyeye göre; Irak’ın Kut Kasabası'nda olup, Türk Şehitliği olarak kabul edilen ve yukarıda bahsedilen ölçü ve mevkideki arazinin Türkiye Cumhuriyeti'ne mülk olarak verildiğinin kabul edildiği, bu kararının icrasına da Maliye Veziri'nin memur olduğu belirtiliyordu (BCA., 30..10.0.0 / 259.744..7.,8 (1935.12.2)).

Irak Kralı'nın iradesinin çıkması üzerine derhal harekete geçen Irak Hariciye Vezareti, durumu Türkiye'nin Bağdat Elçiliği'ne bildirmiştir. 11 Mayıs 1933 tarih ve 4062 sayılı yazısında Irak Hariciye Vekaleti, şimdiye kadar yaşanan gelişmeleri aktarıp, söz konusu arazinin Türkiye Cumhuriyeti'ne hibe edilmesi kararını aldıklarını belirterek saygılarını sunmuştur (BCA., 30..10.0.0 / 259.744..7., 7 (1935.12.2)). 
Irak Devleti nezdindeki işlemlerin tamamlanması ve neticenin Bağdat Elçiliği'ne bildirilmesiyle birlikte artık Türk Şehitliği arazisi Türkiye Cumhuriyeti'nin mülkiyetine geçmiş oluyordu. $\mathrm{Bu}$ çerçevede Bağdat Elçiliği fazla vakit etmeden hemen Türk Hariciye Vekilliği’ni bilgilendirmiştir.

Zira Türkiye'nin Bağdat Elçiliği'nden Hariciye Vekaleti'ne gönderilen 14 Mayıs 1933 tarih ve 15L sayılı yazıda; Irak Hariciye Nezareti'nin Türkiye'nin Bağdat Elçiliği'ne gönderdiği bir yazı ile Irak şeyh ve eşrafindan Rebia Emiri Ali El-Emir'in Kutü'l Amare'deki Türk Şehitliği arazisini Türkiye Cumhuriyeti'ne hibe etmek suretiyle mülkiyet hakkından feragat ettiği ve bu arazinin Türkiye Cumhuriyeti tarafından mülk olarak edinildiği, devir-teslim konusundaki gerekli işlemlerin de tamamlandığı bildirilmiştir. Yine aynı yazıda, alınan kararla ilgili olarak yukarıda açıklanan- Irak Meclis-i Vüzera kararı ile Irak Kralı'nın iradesinin de ekte verildiği ifade edilmekteydi (BCA., 30..10.0.0 / 259.744..7., 5 (1935.12.2)).

Buna göre; Şehitlik arazisi 7988 mt $^{2}$ yüzölçümünde olup Kutü'l-Amare şeyh ve eşrafından Rebia Emiri Ali El-Emir tarafından Türkiye'ye hibe edilmiştir. Ardından Irak kanunları çerçevesinde devir-teslim işlemlerinin nasıl gerçekleştiği açıklanmıştır (BCA., 30..10.0.0 / 259.744..7., 5 (1935.12.2)).

\section{Rebia Emiri Ali El-Emir'in Ödüllendirilmesi}

Türkiye'nin Bağdat Elçiliği, yukarıdaki gelişmelerin yanı sıra Hariciye Vekaleti'ne iki de teklifte bulunmaktaydı. İlki, Türkiye'ye ve Türklere karşı samimi duygular taşıyıp bağl1lığını gösterdiği için şehitlik arazisinin asıl sahibi olan Rebia Emiri Ali El-Emir'e Türk Hükümeti namına teşekkür mahiyetinde bir takdirname gönderilmesi ve Hilal-i Ahmer (Kızılay) Madalyası ile de taltif edilmesi önerisidir (BCA., 30..10.0.0 / 259.744..7., 5 (1935.12.2)).

Elçiliğin ikinci teklifi ise Türk Şehitliği'ne ilişkindir. Şehitliğin 1933 yılındaki durumu hakkında bazı bilgiler veren elçilik, önce, I. Dünya Savaşı'nın Irak Cephesi’nde yaşanan Kutü'l Amare Kuşatması ile Zaferi'nin, milli ve askeri övünç kaynaklarımızdan biri olduğu için zaferin kazanılmasının hemen akabinde ordu tarafından bu şehitlik arazisi dahilinde bir abide inşa edildiğini hatırlatmıştır. Sonrasında, her ne kadar bu abide 1933 yılı itibariyle yıpranmış ve önemli bir tadilata muhtaç hale gelmişse de, söz konusu şehitlik arazisinin devir-teslim işlemlerinin ardından gerekli düzenlemelerin hemen yapılabileceğini ifade etmiştir. Zira şehitlik arazisinin Türk Hükümeti tarafından temlik edilmesiyle birlikte bu abide ile şehitliğin muhafazası ile imarının, Türk milleti için milli ve askeri bir şeref borcu olduğunu vurgulamıştır. Üstelik, Türk Şehitliği’nin karşısında yer alan İngiliz mezarlığının oldukça mamur ve düzenli olması, Türkiye'ye sempatiyle bakan Irak halkı arasında mukayeseye sebep olup, şehitliğimizin bakımsızlığının halkın nazarında Türkiye'nin kınanması gibi bir durum oluşturduğu belirtilerek, Türk Şehitliği'nin acilen imarına başlanması gerektiği ifade edilmiştir (BCA., 30..10.0.0 / 259.744.. 7., 5 (1935.12.2)).

Elçilik, şehitliğin imarı ve idaresi için de ivedi olarak aşağıdaki hususların yerine getirilmesini istemekteydi. Bunlar;

1. Şehitlik etrafında duvar inşaası,

2. Mevcut abidenin tamiri,

3. Bekçi tayin edilmesi,

4. Şehitlikte oluşturulacak bahçenin su bedelinin karşılanması, idi (BCA., 30..10.0.0 / 259.744..7., 6 (1935.12.2)).

İlk yapılacaklar bağlamında ise, duvar yapımı ile abidenin tamirat masrafının tespit edilebilmesi için Bağdat'tan Kutü'l-Amare'ye bir mühendis getirtilmesi gerektiği, bunun için de acilen elçilik bünyesine bir miktar para gönderilmesinin şart olduğu belirtiliyordu (BCA., 30..10.0.0 / 259 . 
744..7., $6(1935.12 .2))$.

Gerekli malumatı alan Hariciye Vekilliği, biri Genelkurmay Başkanlığı'na diğeri de Başvekalet'e olmak üzere gönderdiği iki yazıyla gelişmelerden ilgili mercileri haberdar etmiş ve kendilerinden görüş istemiştir.

Hariciye Vekilliği'ne ilk cevap Genelkurmay Başkanı Fevzi Çakmak'tan gelmiştir. Çakmak, gönderdiği yazıda; Ali El-Emir'e göstermiş olduğu teveccühten dolayı hükümet tarafindan bir takdirname ile Hilal-i Ahmer (Kızılay) Madalyası verilmesinin çok yerinde bir davranış olacağını bildirmiştir. Kutü'l-Amare'deki Türk Şehitliği'nin düzenlenmesine ilişkin belirtilen istekler konusunda ise, şehitliğin etrafına duvar çekilmesi, mezarlık parkının tanzimi, mevcut abidenin tamiratı ve bir bekçi tahsisi hususlarında ihtiyaç duyulan paranın Bağdat Elçiliği tarafından tespit edilerek bildirilmesi için gerekli emirlerin verilmesi istenmiştir (BCA., 30..10.0.0 / 259 . 744..7., $9(1935.12 .2))$.

Gerekli malumatı alan Hariciye Vekilliği, Başvekalet'e yazdığ 24 Haziran 1933 ve 38114/ 712 sayılı yazı ile Irak şeyh ve eşrafından Rebia Emiri Ali El-Emir'in Kutü'l-Amare'deki Türk Şehitliği arazisini Türkiye Cumhuriyeti'ne hibe ettiği, böylelikle Türkiye ve Türklere samimi duygu ve bağlılığını göstermiş olduğu konusundaki bilgilendirmesini yapmıştır. Aynı yazı ile Başvekalet'e, Bağdat Elçiliği’nin teklifi ile Türk Hükümeti adına Ali El-Emir'e bir takdirname gönderilmesinin, aynı zamanda bir Hilal-i Ahmer (Kızılay) Madalyası ile taltif edilmesinin uygun olup olmayacağı sorulmuş, onay verildiği takdirde gereğinin yapılacağı bildirilmiştir. Benzer bir yazıyla, Genelkurmay Başkanlığı'nın taltif teklifinden haberdar edildiği ve başkanlığın Kutü'l-Amare Şeyhi'nin bu şekilde ödüllendirilmesinin münasip olacağına dair kanaat bildirdiği yine Hariciye Vekilliği'nin yazısında yer almıştır (BCA., 30..10.0.0 / 259.744..7., 4 (1935.12.2)).

Bunun üzerine Başvekil Müsteşarlığı, Hariciye Vekilliği’ne gönderdiği 5 Aralık 1935 tarihli ve 6/3372 sayılı yazıda, 24 Haziran ve 14 Ağustos 1933 tarihli ve 38114/712, 41827/895 sayılı yazıya cevap vererek, Rebia Emiri Ali El-Emir'in taltifi hakkındaki evrakın sonuçsuz kaldığı, bu nedenle evvel emirde Ali El-Emir'in ne suretle taltifinin düşünülmekte olduğu sorularak kendilerinin bilgilendirilmesi istenmiştir (BCA., 30..10.0.0 / 259.744..7., 1 (1935.12.2)).

Hariciye Vekaleti ise, söz konusu yazıya 2 Eylül 1937'de verdiği cevapta, Bağdat Elçiliği’nin teklif ettiği bir "Takdirname" ve "Hilal-i Ahmer (Klzllay) Madalyası" ile Ali El-Emir'in taltif edilebileceğinin, hatta Genelkurmay Başkanlığı'nın da bu kararı uygun bulduğunun daha önce Başvekalete arz edildiği hatırlatılarak, Ali El-Emir'in bu suretle taltifinin münasip olup olmayacağı sorulmuştur (BCA., 30..10.0.0 / 193.325..6., (1935.11.20)).

Ancak Başvekillik’ten uzun bir süre cevap gelmediği için Hariciye Vekilliği bir kez daha harekete geçerek, ilgili cevabın acilen kendilerine gönderilmesini istemiş̧ir (BCA., 30..10.0.0 / 259.744..7., 3 (1935.12.2)).

Başbakanlık Cumhuriyet Arşivi'nden elde edilen belgeler, dolayısıyla edinilen bilgiler burada kesilmektedir. Bu nedenle taltif işleminin tam anlamıyla nasıl gerçekleştiği ve sonuncunun ne olduğu konusunda çok fazla malumat sahibi olamıyoruz.

\section{Kutü'l-Amare Türk Şehitliği Hakkında Bazı Meseleler}

Arşiv belgelerinden elde edilen bilgiler bu şekilde iken şimdiye kadar yayımlanmış bazı eserlerde ve bu eserlere kaynaklık eden hükümet kurumlarının internet sitelerinde şehitlik arazisine ilişkin farklı bilgilerin verildiği görülmektedir. 
Şöyle ki, Milli Savunma Bakanlığı resmi internet sitesinin "Şehitliklerimiz" başlıklı linkinde yer alan sayfada Irak'ta iki adet Türk Şehitliği'nin bulunduğu belirtilmektedir. Bunlardan ilki "Băgdat Türk Şehitliği”, diğeri "Kut Türk Şehitliği”dir. Kut Türk Şehitliği hakkında verilen bilgilerde; şehitliğin, eski adı "Kut" olup 1976 yılındaki isim değişikliğinden ötürü "Vasıt" olarak bilinen şehrin aynı zamanda merkezi konumundaki Kut şehrine bağlı "Seyit Haşim Köyü”nde yer aldığ belirtilmektedir. I. Dünya Savaşı'nın Irak Cephesi'nde gerçekleşen Kutü'lAmare Savaşlarında şehit düşüp isimleri tespit edilebilen 7 subay ve 43 ere ait mezarın bulunduğu bu şehitliğin arazisinin ise 1952 y1lında Iraklı bir kadın tarafından Türkiye Cumhuriyeti'ne bağışlandığı ve aynı yıl şehitliğin yapıldığ 1 belirtilmektedir (MSB. Resmi İnternet Sitesi, Erişim Tarihi: 02.11. 2015.http://www.msb.gov.tr/Sehitlikler/ YurtDisiSehitlikleri).

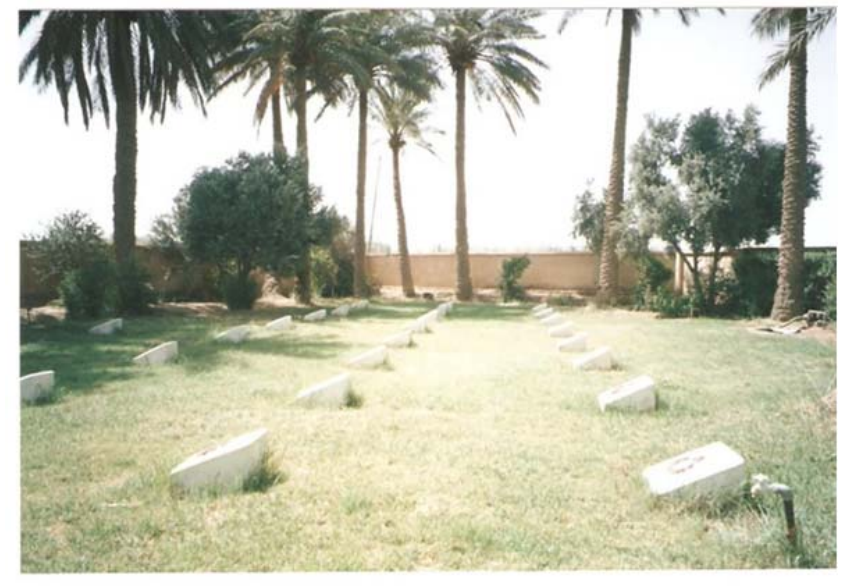

Fig. 5. Kut Türk Şehitliği Kaynak: http://www.msb.gov. tr/Sehitlikler/YurtDisiSehitlikleri

Öte yandan, 25 Kasım 2013 tarihinde Türkiye Cumhuriyeti Bağdat Büyükelçiliği’nden Irak'ta bulunan şehitlikler hakkında e-mail yoluyla alınan bilgilere dayanılarak hazırlanmış bir çalışmada da, Kut Türk Şehitliği arazisini bağışlayan kadının Türk dostu Ali Emir Rafia olduğu ifade edilmektedir. Yine aynı kaynakta, şehitlikte yalnızca dikili bir abidenin bulunduğu, beton mezar taşlarının da simgesel olduğu vurgulanmaktadır (Dönmez 2014, 148-149).

$\mathrm{Bu}$ noktada, verilen bu bilgiler ile belgelerdeki bilgiler karşılaştırıldığında bazı önemli benzerlikler ile çelişkilerin olduğu görülecektir. En başta, bahsedilen her iki şehitliğin de Kut'ta bulunması, aslında ikisinin de aynı şehitlik olduğunu düşündürmektedir. Bununla birlikte şehitlik arazisinin bağış yoluyla Türk Hükümeti'ne tahsis edildiğinin, şehitlikte bir abidenin bulunduğunun belirtilmesi diğer benzer yönlerdir.

Buna karşın, bağışçının kadın olması şeklindeki bilgiler ile şehitlik arazisinin 1952 yılında bağışlandığının ve aynı yıl şehitliğin inşa edildiğinin belirtilmesi, Bağdat Elçiliği belgelerindeki bilgilerle örtüşmeyen en önemli noktalardır.

Elçilik belgelerinde bağışçının, doğrudan doğruya şeyh ve eşraf elkabı ile tanımlanıp, erkek ismiyle zikredilen Rebia Emiri Ali El-Emir olduğu ifade edilirken, Milli Savunma Bakanlığ1 resmi sitesinde bağış̧̧ı -isim verilmeden- kadın olarak tanımlanmakta, hatta araştırma eserinde de bu kadının isminin Ali Emir Rafia olduğu belirtilmektedir. Burada isim benzerlikleri önemli oranda dikkat çekse de bir kadın isminin Ali El-Emir olabilmesi, hatta bu kadının şeyh ve eşraf olarak nitelendirilmesi oldukça çarpıcı bir tutarsızlıktır.

Şehitlik arazinin tahsis tarihi hakkındaki çelişki ise yine Milli Savunma Bakanlığı'nın resmi internet sitesinde verilen "Băgdat Türk Şehitliğ $i$ " hakkındaki bilgilerle daha da karmaşık hale gelmektedir ki belki de sehven yapılmış bir hatanın aydınlatılması konusunda da fikir verir mahiyettedir. Şöyle ki, internet sitesinde, Irak'1n Bağdat şehrinde yer alan Türk Şehitliği arazisinin 1937 yılında Irak Hükümeti'nin onayı ile Türkiye Cumhuriyeti'ne tahsis edildiği belirtilmektedir. 1952 yılında önemli bir tamirat görmüş olan bu şehitlikte 204 sembolik mezar taş1 bulunmaktadır (MSB. Resmi İnternet Sitesi, http://www.msb.gov.tr/Sehitlikler/YurtDisi Sehitlikleri, Erişim Tarihi: 02.11.2015). 
Görüldüğü üzere, Bağdat’taki Türk Şehitliği arazisi 1937 yılında Irak Hükümeti’nin onay1 ile Türkiye Cumhuriyeti'ne tahsis edilmiştir. Tahsis tarihi ile tahsis şekline dikkat edildiğinde, Rebia Emiri Ali El-Emir'in arazisini hibe etme süreci ve şekliyle örtüştüğü görülmektedir. Zira Ali El-Emir, bağış için bürokratik yazışma trafiğine 1932 'de başlamış ve yöntem olarak önce Irak Hükümeti'ne toprağ 1 hibe etmiş ardından Irak Devleti gerekli mercilerden onay almak suretiyle bu araziyi Türkiye'ye bırakmıştı. Dahası, yazışmalar 1937'ye sürmekte ve bu tarihte Ali El-Emir'in ödüllendirilmesinin düşünüldüğü kararlarıyla sona ermekteydi. Dolayısıyla, iki şehitliğin sahiplenilme tarihlerinin siyasi ve idari yazışmalar sırasında sehven karıştırıldığ düşünülebilir. Bu çerçevede, aslında 1937'de bağış yoluyla Türk Hükümeti'ne devredilen arazinin Bağdat Türk Şehitliği arazisi değil, Kut Türk Şehitliği arazisi olması gerekmektedir.

\section{Sonuc}

Osmanlı Devleti'nin I. Dünya Savaşı'nda İngilizlerle mücadele ettiği en önemli cephelerden biri de Irak Cephesi'dir. 5 Kasım 1914'te İngilizler tarafından açılan cephe, İngilizlerin hızlı ilerleyişiyle genişlemiş ve İngiliz orduları kısa bir süre içerisinde Kutü'l-Amare'ye kadar gelmişlerdir. Bununla birlikte İngiliz ordusuna vurulan en önemli darbe, General Townshend komutasındaki 13.309 mevcutlu İngiliz ordusunun başlarındaki 5 general ile birlikte kuşatılarak esir alınması suretiyle gerçekleştirilmiştir. Hatta General Townshend'ın Halil Bey'e teklif ettiği rüşvete karşılık Paşa'nın verdiği cevap ve teklifi geri çevirmesi, gerçekten çok anlamlı olup, Türk askerinin her ne şart altında olursa olsun asla onurlu duruşundan vazgeçmeyeceğini ortaya koymuştur.

Sonuçta 29 Nisan 1916'da İngiliz birlikleri 2.000 mevcutlu Türk askerine teslim olmak zorunda kalmıştır. Halil Bey'in, Kut'u teslim aldığı zaman Townshend'a söylediği sözler de yine Türklerin savaşta mertlikten, barışta hoşgörülükten yana bir millet olduğunu gösteren önemli bir kanıt olmuştur.

Öte yandan, burada kazanılan zafer ve esir edilen İngiliz askeri, İngiliz ordularının yenilmezlik algısını zedelemiş, Hasta Adam olan Osmanlı'nın ordularına esir vererek tüm dünyada itibar kaybına uğramıştır.

Kutü'l-Amare Zaferi'nin Türk tarafı açısından en önemli sonuçlarından bir diğeri hiç şüphesiz Musul Meselesi bağlamında kaşımıza çıkmaktadır. Öyle ki, burada elde edilen başarılar neticesinde İngiliz ordusunun duraksaması Musul ve çevresinin 30 Ekim 1918 tarihli Mondros Mütarekesi'nden önce ele geçirilmesini engellemiştir.

Ayrıca Kutü'l-Amare Zaferi'nin hemen ardından, 13. Kolordu'nun İran'a gönderilmesi, İngiltere ve Rusya gibi iki müttefik gücün Irak üzerinde birbirleriyle doğrudan irtibata geçmesini engellemiş, bu ise savaşın kaderini ve Osmanlı Devleti'nin geleceğini etkileyen önemli bir hamle olmuştur.

Dolayısıyla tarihimizde bu kadar önemli olan -ancak günümüzde unutulmaya yüz tutan- bir zaferin ebedileşmesi bir anıt ve orada hayatlarını kaybeden şehitlerimize de daimi bir ikametgah hazırlanması geride kalanlara şart olmuştur. Bu vazife kısa bir süre içerisinde icra edilmiş ve bölgede bir abide ile şehitlik hazırlanmıştır. Ancak Türk Şehitliği'nin bulunduğu arazi, Irak Devleti kurulunca Irak Vatandaşı Rebia Emiri Ali El-Emir'in şahsi mülkü haline gelmiştir. Bununla birlikte Rebia Emiri Ali El-Emir'in 1932 yılında söz konusu araziyi Türkiye Cumhuriyeti'ne hibe etmeye karar vermesi neticesinde gerek Irak makamları gerekse Türk makamları arasında uzun soluklu bir yazışma trafiği başlamıştır.

Sonuçta, gerekli işlemlerin tamamlanmasıyla birlikte şehitlik arazisi Irak Hükümeti yoluyla Rebia Emiri Ali El-Emir' tarafından Türk Hükümeti'ne bağışlanmıştır.

Akabinde Türk Hükümeti, Bağdat Büyükelçiliği’nin teklifi ile Irak'ın şeyh ve eşrafindan 
olup araziyi bağışlayan Rebia Emiri Ali El-Emir'i bir vefa ve minnet borcu olarak ödüllendirmek istemiştir. Ödüllendirmenin, takdirname gönderilmesi ve Hilal-i Ahmer (Kızılay) Madalyası ile taltif edilmesi şeklinde yapılması öngörülmekteydi. Elçilik ayrıca, atıl ve bakımsız kalmış şehitliğin imarı ve idaresi için de bazı isteklerde bulunmuş ve bu istekler de olumlu karşılanmıştır.

Ancak her iki isteğin de sonucunun ne şekilde tecelli ettiği konusunda herhangi bir bilgiye ulaşılamamıştır. Bununla birlikte Rebia Emiri Ali El-Emir'in Bağdat Elçiliğì'nin teklifinde bahsedildiği üzere bir takdirname ve bir Kızılay Madalyası ile ödüllendirildiği düşünülebilir. Zira gerek Bağdat Elçiliği ve Hariciye Vekaleti gerekse Genelkurmay Başkanlığı ile Başvekalet, Bağdat Elçiliği'nin teklifine muhalif bir görüş belirtmemişler veya farklı bir taltif seçeneği sunmamışlardır.

Öte yandan Kutü'l-Amare'deki Türk Şehitliği ve arazisi hakkında bazı ihtilaflı noktalar da bulunmaktadır. Nitekim Bağdat Elçiliği'nin resmi yazısında doğrudan doğruya şeyh ve eşraf elkabı ile tanımlanıp erkek ismiyle zikredilen Rebia Emiri Ali El-Emir'in, -eğer ki aynı kişi iseMilli Savunma Bakanlığı resmi sitesinde kadın olarak ifade edilmesi, öte yandan Irak’ta kadınların şeyh olup olmayacağı durumunun soru işareti olması, Kutü'l Amare'deki Türk Şehitliği arazisi 1930'lu yıllarda hibe edilmişken, aynı arazinin sitede 1952 yılına tarihlendirilmesi gibi çelişkiler, -eğer ki belgelere dayalı mantıklı bir açıklaması yoksa- sanırız ki eldeki bilgilerin sorgulanmadan bilgi paylaşımına açılmasından kaynaklanmaktadır.

Bunlar içerisinden özellikle tarihlendirmelerde konusunda iki şehitliğin sahiplenilme tarihlerinin siyasi ve idari yazışmalar sırasında sehven karıştırıldığı düşünülebilir. Bu çerçevede aslında Bağdat Türk Şehitliği arazisinin 1952 yılında, Kut Türk Şehitliği arazisinin ise 1937'de hibe edilmiş olabileceği seçeneği üzerinde durulabilir.

$\mathrm{Bu}$ tür çelişkili bilgilerin ortaya çıkmasındaki en önemli sebebin ise bilgi ve belge eksikliğinden kaynaklandığı söylenebilir. Zira devlet kurumlarının sahip olduğu bilgiler, birbirleriyle örtüşmemektedir. Daha önce açıklandığı üzere, Milli Savunma Bakanlığı'nın konuyla ilgili verdiği bilgi ile Başbakanlık Cumhuriyet Arşivi'nden elde edilen bilgiler, belki de eksik olduğundan, birbirleriyle çelişmektedir. Her bir kurum, artık tarihe mal olmuş gelişmelerle ilgili elindeki belgelerin tamamını tasnif edip açıklamış olsa sanırız ki tarihi gelişmeleri daha açıklıkla inceleyip değerlendirebiliriz.

Yapılan araştırmadan çıkarılabilecek bir diğer sonuç, Türk bürokrasisinin işleyişine dairdir. Keza Irak Hükümeti, Rebia Emiri'nin başvurusu ile hemen harekete geçip 1932 ve 1933 yıllarında Meclis kararı ile Kral iradesini çıkartıp devir işlemini gerçekleştirirken, Türk Hükümeti sadece bir takdirname ve madalya ile taltif etme konusundaki kararı almakta oldukça zorlanmıştır. 1933 yılında başlayıp, 1937 yılına kadar konuyla ilgili yazışmaların sürmüş olması, dahası hala kesin ve ne şekilde ödüllendirildiğine dair bir bilgiye ulaşılamaması bürokrasinin ne kadar yavaş ilerlediğini göstermektedir. 


\section{KAYNAKÇA}

Apak R. (1988).Yetmişlik Bir Subayın Hatıraları. Ankara 1988.

Barber C. H. (1918). Besieged in Kut and After. London 1918.

Bayur Y. H. (1991). Türk Inkılâbı Tarihi. Cilt III, Kısım I. Ankara 1991.

Bayur Y. H. (1991). Türk Inkılâbı Tarihi. Cilt III, Kısım III. Ankara 1991.

"Bağdat Türk Şehitliği”. (n.d.). MSB, Resmi Internet Sitesi. Erişim Tarihi: 02.11.2015: http://www. msb.gov.tr/Sehitlikler/YurtDisiSehitlikleri.

Dönmez C. (2014). “I. Dünya Savaşıyla İlgili Yurt Dışındaki Türk Şehitlikleri”. Gazi Akademik Bakış 7/14 (2014) 137-162.

Erickson E. J. (2009). I. Dünya Savaşı'nda Osmanlı Ordusu Çanakkale, Kutü'l-Amare ve Filistin Cephesi. Çev. Kerim Bağrıaçı. İstanbul 2009.

Gn.kur. ATASE Başkanlığı (1979). Birinci Dünya Harbinde Türk Harbi Irak-Iran Cephesi (1914-1918). Cilt III, Kısım I. Ankara 1979.

Gn.kur. ATASE Başkanlığı (2002). Birinci Dünya Harbinde Türk Harbi Irak-İran Cephesi (1914-1918). Cilt III, Kısım II. Ankara 2002.

Goltz C. V. D. (2012). 20. Yüzyll Başlarında Osmanlı-Alman Ilişskileri “Golç Paşa'nın Hâtırâtı”. Haz. Faruk Yilmaz. İstanbul 2012.

"Halil Kut". (n.d.). Erişim Tarihi: 25.11.https://tr.wikipedia.org/wiki/Halil_Kut.

Harp Mecmuası (2006). Haz. Ali Fuat Bilkan, Ömer Çakır. İstanbul 2006.

Hiçyılmaz E. (1996). Teşkilât-ı Mahsusa ve Casusluk Örgütleri. İstanbul1996.

Hiçyılmaz E. (2002). Esir Kampları Bana Biraz Hürriyet Yollar mısın? İstanbul 2002.

İlhan F. (2015).“Türk'ün Şanlı Tarihi'nden Bir Kesit: Kutü'l-Ammare Zaferi”. Silahlı Kuvvetler Dergisi 425 (2015) 10-17.

"Kut Kuşatması'nın Sonu (Nisan 1916)”. Erişim Tarihi: 25.11.2015 tarihinde şu kaynaktan alınmıştır: https://tr.wikipedia.org/wiki/Dosya:Kut-el-Amara-map.jpg.

"Kut Türk Şehitliği”. (n.d.). MSB, Resmi İnternet Sitesi. Erişim Tarihi: 25.11.2015 tarihinde şu kaynaktan alınmıştır: http://www.msb.gov.tr/Sehitlikler/YurtDisiSehitlikleri.

Longrigg S. H. (1968). 'Iraq, 1900 to 1950 A Political, Social, and Economic History. Oxford 1968.

Mehmet Kenan (1928). Büyük Harpte Irran Cephesi. Cilt II. Ankara1928.

Moberly F. J. (1924), The Campaign in Mesopotamia 1914-1918, II. London 1924.

Ölçen Y. (1992). Birinci Dünya Harbi Irak Cephesi Kutülammare Muharebeleri (29 Nisan 1916-16 Şubat 1917). Yayımlanmamış Doktora Tezi. Ankara Üniversitesi, Türk İnkılap Tarihi Enstitüsü, Ankara 1992.

Özdemir M. (2004).“Birinci Dünya Savaşı’nda Irak Cephesi’nde Propaganda ve Casusluğa Karşı Alınan Tedbirler". Askeri Tarih Araştırmaları Dergisi IV/2 (2004) 55-74.

Sâbis A. İ. (1992). Harp Hatıralartm Birinci Cihan Harbi. Cilt 2. İstanbul1992.

Sakin S. (2010)."Birinci Dünya Savaşı'nda Irak Cephesinde Osmanlı Devleti ile İngiltere Arasındaki Çarpışmalar (1915)". Gazi Akademik Baklş 4/7 (2010) 133-152.

Sorgun T. (2010). Halil Paşa İttihat ve Terakki'den Cumhuriyete Bitmeyen Savaş. İstanbul 2010.

T.C. Başbakanlık Devlet Arşivi Gen. Müd. (1993).Musul-Kerkük ile İlgili Arşiv Belgeleri (1525-1919). Ankara 1993.

Townshend C. V. F. (2007). Irak Seferi ve Esaret. (Terc.Tarih-i Asker-i Osmâni Encümeni). (Sad. Recep Ahıskalı). İstanbul 2007.

“Tümgeneral Charles V. F. Townshend”. Wikipedia. Erişim Tarihi: 25.11.2015. https://tr.wikipedia. org/wiki/Charles_Vere_Ferrers_Townshend.

Üzen İ. (2008). "Türklerin Kutü'l-Amare Kuşatması Sırasında İngiliz Ordusunda Bulunan Hintli Askerlerin Tutumu (Aralık 1915- Nisan 1916)". Gazi Akademik Bakls 2/3 (2008) 81-102. Kaynak: http://www.unesco.org/new/en/culture/themes/creativity/creative-cities-network/interviews-and-articles. 
Arşiv Belgeleri

BCA., 30..10.0.0 / 259.744..7. (1935.12.2).

BCA., 30..10.0.0 / 193.325..6. (1935.11.20). 